\title{
REGULATORY AND LEGAL ISSUES OF INCLUSIVE GENERAL SECONDARY EDUCATION
}

\section{НОРМАТИВНО-ПРАВОВІ АСПЕКТИ ІНКЛЮЗИВНОЇ ЗАГАЛЬНОЇ СЕРЕДНЬОЇ ОСВІТИ}

\author{
Nataliia KRAVCHENKO, \\ candidate of physical and \\ mathematical sciences, associate \\ professor \\ Наталія КРАВЧЕНКО, \\ кандидат фрізико-математичних \\ наук, доцент \\ natalyvkravchenko@gmail.com \\ https://orcid.org/0000-0002-9642-5403 \\ Dmytro VENETSKY, \\ postgraduate student \\ ДМИтрО ВЕНЕЦЬКИЙ, \\ аспірант \\ dima0909971@gmail.com

\section{https://orcid.org/0000-0001-9588-0941} \\ Berdiansk State Pedagogical \\ Бердянський державний \\ University, \\ педагогічний університет \\ $\triangle 4$, Schmidta street, \\ Berdiansk, Zaporizhzhia region, \\ 71100 \\ Original manuscript received: December 16, 2021 \\ Revised manuscript accepted: December 24, 2021
}

\section{ABSTRACT}

The relevance of the topic is resulted from the need to conform current legislation and practices on the rights to equal access to quality education for children with special needs. Regulatory and legal issues of inclusive education were considered in the scientific publications of Ukraine. However, regulatory and legal issues of inclusive general secondary education requires further analysis.

The purpose of the work is to research and analysis of regulatory and legal issues of inclusive general secondary education in the world experience and in the Ukraine in particular.

The legislative process of providing inclusive education in the Ukraine is determined by international regulations. The international strategy for inclusive education is aimed at realizing human rights to education, forming an inclusive society, transforming educational systems, supporting state strategies for inclusive education, modernizing teacher training, and developing mechanisms for investing in inclusive education.

There are fundamentals for individualization of education in the Ukraine. Issues of practical implementation the concept of inclusive education needed to be improved. First, there is a need to amend the laws of 
Ukraine "About education", "About preschool education" and "About general secondary education" in terms of the number of working hours of the assistant educator and assistant teacher in upward. Secondly, the changes should be made regarding the size of groups and classes. The children with only one type of disorder can study within the group.

Key words: Inclusive education, special educational needs, inclusion, general secondary education, regulatory and legal issues of education.

Вступ. Для розвитку України у напрямі відкритого демократичного суспільства та реалізації ії курсу на євроінтеграцію важливою $\epsilon$ відповідність чинного законодавства та практики забезпечення основних прав людини, зокрема, права на рівний доступ до якісної освіти для дітей з особливими потребами.

Приєднавшись до основних міжнародних договорів у галузі прав людини (Декларації ООН про права людини, Конвенції ООН про права інвалідів, права дитини), Україна взяла на себе зобов'язання щодо дотримання загальнолюдських прав, зокрема, забезпечення права на освіту дітей із особливими освітніми потребами.

Публікації, присвячені нормативно-правовим аспектам інклюзивної освіти, представлені в наукових виданнях України (Криворучко, Шевченко, 2021; Щербяк, 2018). Так, адміністративноправове регулювання інклюзивної освіти розглянуто в роботі (Щербяк, 2018). Разом з тим потребують додаткового аналізу нормативно-правові аспекти інклюзивної загальної середньої освіти.

Метою роботи $є$ дослідження й аналіз нормативно-правових аспектів інклюзивної загальної середньої освіти та їх реалізація у світовому досвіді і в Україні зокрема.

Матеріали та методи дослідження. У дослідженні використано загальнонаукові теоретичні (вивчення наукових джерел, аналіз, синтез, порівняння, інтерпретація, узагальнення, систематизація) методи.

Виклад матеріалу. Законодавчий процес забезпечення інклюзивної освіти в Україні багато в чому визначений міжнародними нормативно-правовими актами. Так, уперше було визнано, що кожна людина має право на освіту і зафріксовано в Загальній декларації прав людини (Загальна декларація..., 1948). У ній були проголошені як соціальні, економічні та культурні, так політичні та громадянські права. У іï̈ першій статті міститься історичне положення про свободу та рівність гідності та прав особистості кожної людини: "Всі люди народжуються вільними та рівними у своїй гідності та правах".

У Декларації прав дитини представлені основні засади дотримання таких прав. Так, у Принципі 5 закріплено положення про те, що "дитині, яка $\epsilon$ неповноцінною у фізичному, психічному чи соціальному відношенні, повинні забезпечуватися спеціальні режим, освіта та турбота, необхідні з огляду на його особливий стан" (Декларація прав дитини, 1959). 
Конвенція “Про боротьбу з дискримінацією в галузі освіти”, прийнята в 1960 р., уперше вказала на необхідність єдиних підходів до організації процесу навчання всіх дітей, що усувало будь-які форми дискримінації в галузі освіти та заохочувало загальну рівність можливостей та ставлення до всіх (Конвенція про боротьбу 3 дискримінацією в галузі освіти, 1960). Отже, у ній було визначено загальнодоступність та рівні умови щодо якості навчання. Надалі Міжнародний пакт про економічні, соціальні та культурні права закріпив право кожної людини на доступну освіту (Міжнародний пакт про економічні..., 1966).

У 1970-х р. у ряді документів було уточнено позиції суспільства щодо інтеграції в соціум людей з розумовою відсталістю, визначені права інвалідів (Декларації ООН “Про права розумово відсталих осіб”, 1971; “Про права інвалідів”, 1975). У Світовій програмі дій щодо інвалідів, яка гідно завершила Всесвітній рік інвалідів (1982р.), наголошувалося, що їх освіта по можливості повинна проходити в рамках загальної шкільної системи, а державні закони, які розробляються та приймаються щодо обов'язкової освіти, мають поширюватися на дітей з усіма видами інвалідності, у тому числі найважчими їі формами. Уперше було звернуто увагу на гнучкість, індивідуальність, доступність і всеосяжність системи освіти, а також необхідність створення особливих умов у загальній системі освіти (щодо підготовки кадрів, моніторингу ситуацій, формування спеціальних служб супроводу). У цій Програмі розглядалися ситуації, у яких діти 3 різних причин не мали можливості вчитися в спільній системі освіти. У таких випадках передбачалася організація спеціальних навчальних закладів, де якість навчання була б рівнозначною та взаємопов'язаною із загальною системою освіти (Всесвітня програма дій..., 1982).

Основний імпульс розвитку інклюзивного навчання був наданий у 1994 році на Всесвітній конференції з навчання дітей з особливими потребами, яка проходила в Іспанії. Відповідно до укладеної декларації інклюзивна освіта має спиратися на педагогічні принципи, засновані на утвердженні того, що відмінності між дітьми $є$ нормою та навчання необхідно адаптувати до їхніх потреб із застосуванням підтримки та спеціалізованих послуг. Крім того, важливою умовою реалізації інклюзивної моделі стає підготовка освітян. Вона передбачає отримання знань та вмінь з оцінки особливих потреб, адаптування змісту навчальних планів; використання допоміжних технологій; індивідуалізацію викладання. Зазначимо, що педагоги мають пройти додаткову підготовку на основі гнучкого підходу, який охоплює всі типи розумових та фізичних вад. Особливо варто наголосити на необхідності створення служб зовнішньої підтримки інклюзивних шкіл - ресурсних центрів, здатних забезпечувати методичний супровід інклюзивного процесу, підвищення кваліфікації педагогів; здійснювати наукові дослідження й цим сприяти стабільності та ефективності інклюзивної освіти. Крім того, декларація характеризує умови (організаційні, 
методичні, технологічні), які необхідно забезпечити з метою якісної реалізації інклюзивної моделі освіти (Саламанська декларація..., 1994).

У 2004 р. ЮНЕСКО було розроблено документ "Освіта для всіх. Основні ініціативи”, у якому визначено дев'ять основних ініціатив, що вимагають консолідації міжнародних зусиль задля досягнення ОДВ. Цінність цього документа полягає в тому, що для кожної ініціативи визначено основні завдання та розроблено механізми їх реалізації. Завданнями ініціативи “Права дітей з особливими потребами на освіту: Щодо інклюзії” були визначені: спонукати відповідальних за розробку політики брати участь у визначенні перешкод у системі освіти та розробці шляхів їх подолання; сприяти включенню питання рівного доступу до освіти осіб з особливими потребами; посилити роботу у сфрері підвищення обізнаності щодо прав осіб з особливими потребами на освіту; забезпечити включення питання про права осіб з особливими потребами як одного з критеріїв досягнення ОДВ; посилити взаємну підтримку та співпрацю учнів, вчителів та батьків. У цьому документі пропонуються такі шляхи досягнення намічених завдань: розробка політичних рекомендацій щодо реформування національної освітньої політики інклюзії; створення потенціалу для розширення підходів до інклюзивного навчання; видання навчальних матеріалів 3 метою сприяння розробці інклюзивних методик; використання нових інформаційних та комунікаційних технологій з метою створення "Нових можливостей для осіб з особливими потребами" (The Flagship on Education for All..., 2004).

Конвенцією про права осіб з інвалідністю (2006 р.) закріплюється право тих, хто має обмежені можливості, на отримання необхідної індивідуалізованої підтримки (тьюторського супроводу) всередині системи загальної освіти. Тьюторський супровід є дієвим інструментом підтримки учнів, загалом дітей з особливими освітніми потребами i розуміється як педагогічна діяльність, спрямована на індивідуалізацію освіти: виявлення та розвиток освітніх мотивів та інтересів учня, пошук освітніх ресурсів для створення індивідуальної освітньої програми, роботу з освітнім замовленням сім'ї, формування навчальної та освітньої рефрлексії учня. Конвенція встановлює зміни в підготовці вчителів, а саме просвітництво щодо інвалідності та використання відповідних підсилювальних та альтернативних методів, способів та форматів спілкування; навчальних методик та матеріалів для підтримки інвалідів (Конвенція про права осіб з інвалідністю, 2006).

Проаналізувавши законодавство країн Європи, можна визначити основні тенденції.

У багатьох державах було вирішено питання щодо вступу до закладів вищої освіти людей з інвалідністю. Кіпрський Закон про вступні іспити легітимізує права людей з інвалідністю, наприклад: використовувати індивідуальне обладнання. У Греції існує законодавство, яке регулює вступ до університетів абітурієнтів 3 інвалідністю. Федеральний Акт про університети Австрії захищає права на спеціальні екзаменаційні методики 
для людей з інвалідністю. В Угорщині національний Акт про вищу освіту дає визначення студента з інвалідністю. У Португалії щороку відповідно до законодавства, що регулює національний процес вступу до університетів, виділяється спеціальна квота - 2\% для студентів із фрізичними та сенсорними захворюваннями (Міжнародні стандарти та європейська практика..., 2011).

Окремо варто спинитися на підтримці здобувачів освіти 3 інвалідністю. В Угорщині студенти з інвалідністю можуть бути звільнені від вивчення деяких курсів. У Данії студенти, яким необхідна спеціальна педагогічна підтримка, мають право отримати все необхідне відповідно до Закону про соціальну педагогічну підтримку у сфері вищої освіти. У Словаччині для університетів та коледжів існує зобов'язання встановлювати розумні умови навчання для студентів з інвалідністю, які стосуються їх спеціальних потреб без зниження вимог до виконання програми навчання (Міжнародні стандарти та європейська практика..., 2011).

Також поширеною практикою є створення спеціальних структур в університетах, які займаються питаннями студентів з інвалідністю. У багатьох університетах Австрії існує позиція представників від організації консорціуму за зрівняння прав для людей 3 інвалідністю та хронічними захворюваннями. У кожному університеті та інституті Швеції $€$ спеціальний координатор, який працює із проблемами освітньої підтримки студентів 3 інвалідністю. В університеті Ісландії також створено Комітет з інвалідності, який вирішує проблеми доступності, ресурсів, технічні проблеми тощо, які виникають у людей з інвалідністю (Міжнародні стандарти та європейська практика..., 2011).

У деяких розвинених країнах система спеціальної освіти була практично ліквідована. У Великобританії згідно із законами "Про особливі потреби в освіті та інвалідності" (Special Educational Needs and Disabilities Act, 2001) та "Про дітей та сім'ї" (Chidren and Families Act, 2014) за замовчуванням діти з особливими освітніми потребами навчаються школах в основному потоці. Законодавство передбачає функціонування спеціальних та незалежних шкіл, де також можуть навчатися діти з обмеженими можливостями здоров'я.

Аналіз нормативно-правових актів розвинених країн довів, що міжнародна стратегія інклюзивної освіти спрямована на реалізацію прав людини на освіту, формування інклюзивного суспільства, трансформацію освітніх систем, підтримку державних стратегій інклюзивної освіти, модернізацію професійно-педагогічної підготовки вчителя, розроблення механізмів інвестування інклюзивної освіти. Програмні дії ЮНЕСКО полягають у розробці методологічних, організаційних, технологічних підходів моделі інклюзивної освіти.

Про необхідність інклюзивної освіти в Україні вперше заговорили на початку 2000-х років. Концепція ранньої соціальної реабілітації дітейінвалідів, схвалена Постановою КМУ № 1545 від 12.10.2000 р. (Концепція ранньої соціальної реабілітації..., 2004), серед Загальних 
положень містить фразу: “...на зміну ізольованому інтернатному вихованню дітей-інвалідів повинно прийти інтегроване навчання та виховання...”, а у “напрямках реабілітації” передбачає “...перебування дитини-інваліда у дитячому колективі, без ізоляції від суспільства (як це відбувається у закритих інтернатних установах), в умовах звичайного середовища..." та “...поступову інтеграцію дітей-інвалідів до дитячих дошкільних закладів та загальноосвітніх шкіл".

Державний стандарт початкової загальної освіти для дітей, які потребують корекції фрізичного та (або) розумового розвитку, був прийнятий у 2004 році. Пункт 9 цього документа зобов'язує всі загальноосвітні навчальні заклади, незалежно від типу, форми власності та підпорядкування, працювати відповідно до цього Державного стандарту, якщо в установі навчаються діти з особливими потребами (Державний стандарт..., 2013).

Згідно 3 Комплексною програмою освіти та професійної підготовки інвалідів, затвердженою загальним наказом МОН та АПН України від 26.11.2002 р., було розроблено нормативи чисельності та запроваджено в спеціальних школах-інтернатах, центрах професійної, соціальної, медичної реабілітації інвалідів, навчально-виробничих підприємствах та ВН3 I-IV рівнів акредитації посади вчителів (викладачів) валеології, реабілітологів, психологів, профконсультантів, сурдоперекладачів та інших спеціалістів у межах виділених асигнувань (Про затвердження Програми професійної підготовки..., 2002).

Згідно з наказом Президента України № 926/2010 від 30 вересня 2010 р. “Про заходи пріоритетного розвитку освіти в Україні" 2011 рік оголошено Роком освіти та інформаційного суспільства. В одному 3 пунктів цього наказу (п. 3, п. п. 2) йдеться про впровадження інклюзивного навчання в дошкільних та загальноосвітніх навчальних закладах дітей із особливими потребами (Про заходи щодо забезпечення..., 2010).

Кабінет Міністрів України своєю ухвалою № 872 від 15 серпня 2011 р. затвердив порядок організації інклюзивного навчання в загальноосвітніх навчальних закладах. Цим документом передбачається, що рішення про створення класів з інклюзивним навчанням приймається керівником загальноосвітнього навчального закладу 3 урахуванням освітніх запитів населення за наявності необхідної матеріально-технічної та методичної бази, відповідних педагогічних кадрів та приміщень, що відповідають санітарно-гігієнічним вимогам. Засновник загальноосвітнього навчального закладу виділяє в установленому порядку кошти для забезпечення безперешкодного доступу до будівель та приміщень таких закладів дітей з особливими освітніми потребами, створення відповідної матеріально-технічної та методичної бази; забезпечує підвищення кваліфікації педагогічних працівників щодо надання освітніх послуг дітям 3 особливими потребами в класах, сприяє здійсненню інноваційної діяльності, здійснює заходи щодо придбання транспортних засобів для підвезення 
дітей до місця навчання та додому (Порядок організації інклюзивного навчання..., 2011).

23 травня 2017 року Президент України підписав документ “Про внесення змін до Закону України “Про освіту" щодо особливостей доступу осіб з особливими освітніми потребами до освітніх послуг", де вперше на законодавчому рівні визначені такі поняття, як "інклюзивне навчання", "особа з особливими освітніми потребами", “індивідуальна програма розвитку" та ін. (Про освіту, 2017).

12 липня 2017 року була створена нова служба системної підтримки та супроводу дітей з ООП (інклюзивно-ресурсні центри) шляхом реорганізації психолого-медико-педагогічних консультацій, а Кабінет Міністрів України вніс зміни до Порядку організації інклюзивного навчання в загальноосвітніх навчальних закладах, згідно з якими на кожного учня з ООП складається IПР, де зазначаються конкретні освітні стратегії та підходи, кількість годин і напрями проведення психологопедагогічних, корекційно-розвивальних послуг (Про затвердження Порядку організації..., 2017).

8 червня 2018 року Міністерство освіти і науки України затвердило Примірне положення про команду психолого-педагогічного супроводу дитини з особливими освітніми потребами в закладі загальної середньої та дошкільної освіти (Про затвердження Примірного положення про команду..., 2018).

21 серпня 2019 року задокументовано зміни до Постанови Кабінету Міністрів України “Про встановлення тривалості здобуття освіти у закладах загальної середньої освіти для дітей з особливими освітніми потребами" від 23.04.2003 № 585, зокрема, йдеться про учнів початкової та базової шкіл. На кожному з цих двох рівнів навчання може буди подовжено на рік за рішенням команди психолого-педагогічного супроводу (Про встановлення тривалості здобуття освіти..., 2019).

Незважаючи на правову врегульованість інклюзивної освіти, питання практичної реалізації Концепції розвитку інклюзивної освіти вимагають удосконалення. За результатами соціологічного дослідження Криворучко О. Ю., Шевченко М. С. (Криворучко О. Ю., Шевченко М. С., 2021) були виявлені прогалини, що заважають розвитку інклюзивної освіти. По-перше, це необхідність внесення змін до законів України "Про освіту", "Про дошкільну освіту" та "Про загальну середню освіту" щодо збільшення кількості годин роботи асистента вихователя та асистента вчителя, щоб забезпечити основну педагогічну мету інклюзивної освіти. По-друге, слід внести зміни щодо наповнюваності груп та класів таким чином, аби в межах одного класу могли знаходитися діти лише 3 однаковими видами порушень.

Висновки. Ратифікація основних міжнародних документів зумовила реформування в Україні правового поля, створила умови розробки власної нормативно-правової бази на засадах дотримання загальноприйнятих прав людини, зокрема права на освіту дітей 3 особливими освітніми потребами. 
у вітчизняному законодавстві закладено основи для індивідуалізації освіти, налаштування його під освітні потреби кожної конкретної дитини. Проте існують і деякі проблеми, що перешкоджають упровадженню інклюзії. Наприклад, закріплюючи можливість організації освітнього процесу у фрормі спільного навчання дітей з обмеженнями у здоров"ї та без них, закон віддає вирішення цих питань на розсуд освітніх організацій, які через велику кількість фракторів (недостатні матеріально-технічні умови, відсутність спеціального обладнання, компетентного педагогічного персоналу, відсутність підтримки з боку батьків тощо) часто не можуть реалізувати ідеї інклюзивного навчання.

\section{Література}

Всесвітня програма дій стосовно інвалідів 1982 (Консультативний комітет ООН). Офріційний сайт Верховної Ради України. URL: https://zakon.rada.gov.ua/laws/show/995_427?lang=uk\#Text

Декларація прав дитини. 1959 (Генеральна Асамблея ООН). Офріційний сайт Верховної Ради Украӥни. URL: https://zakon.rada.gov.ua/laws/show/995_384?lang=uk\#Text

Декларація про права розумово відсталих осіб 1971 (Генеральна Асамблея ООН). Офріиійний сайт Верховної Ради України. URL: https://zakon.rada.gov.ua/laws/show/995_119?lang=uk\#Text

Державний стандарт початкової загальної освіти для дітей з особливими освітніми потребами 2013 (Кабінет міністрів України). Офіційний сайт Верховної Ради України. URL: https://zakon.rada.gov.ua/laws/show/848-2004-\%D0\%BF\#Text)

Загальна декларація прав людини 1948 (Генеральна Асамблея ООН) Офріційний сайт Верховної Ради України. URL: https://zakon.rada.gov.ua/laws/show/995_015?lang=uk\#Text

Закон України "Про освіту" (2017). Офріційний сайт Верховної Ради України. URL: https://zakon.rada.gov.ua/laws/show/2145-19\#Text

Конвенція про боротьбу з дискримінацією в галузі освіти 1960 (Генеральна Асамблея ООН) Офріційний сайт Верховної Ради України. URL: https://zakon.rada.gov.ua/laws/show/995_174?lang=uk\#Text

Конвенція про права осіб з інвалідністю 2006 (Генеральна Асамблея
Ооріційний сайт
Верховної Ради України. URL: https://zakon.rada.gov.ua/laws/show/995_g71/ed20061213?lang=uk\#Text

Концепція ранньої соціальної реабілітації дітей-інвалідів // Збірник нормативно-правових актів України щодо діяльності центрів реабілітації дітей із функціональними обмеженнями. Укладачі Крижанівський В., Сварник Н., Скрипка Н. та ін. - Київ: Соцінформ, 2004. - с. 29-30.

Концепція ранньої соціальної реабілітації дітей-інвалідів 2000 (Кабінет міністрів України). URL: Офрічійний сайт Верховної Ради України https://zakon.rada.gov.ua/laws/show/1545-2000-\%D0\%BF\#Text

Концепція розвитку інклюзивного навчання 2010 (Міністерство освіти та науки України). URL: https://mon.gov.ua/ua/npa/pro-zatverdzhennya-kontseptsiirozvitku-inklyuzivnogo-navchannya

Криворучко, О. Ю., Шевченко, М. С. (2021) Адміністративно-правове регулювання інклюзивної освіти у закладах дошкільної та повної загальної середньої освіти в Україні. Правова держава. №. 41, 122-137. DOI: https://doi.org/10.18524/2411-2054.2021.41.225618

Міжнародний пакт про економічні, соціальні і культурні права 1960 (Генеральна Асамблея ООН) Офрічійний сайт Верховної Ради України. URL: 
https://zakon.rada.gov.ua/laws/show/995 042/ed19661216\#Text

Міжнародні стандарти та європейська практика у сфері доступності вищої освіти. URL: https://www.disright.org/ru/info/mezhdunarodnye-standarty-ievropeyskaya-praktika-v-sfere-dostupnosti-vysshego-obrazovaniya

Порядок організації інклюзивного навчання у загальноосвітніх навчальних закладах 2011 (Кабінет міністрів України) Офріційний сайт Верховної Ради України. URL: https://zakon.rada.gov.ua/laws/show/872-2011\%D0\%BF/ed20110815\#Text

Порядок організації інклюзивного навчання у закладах вищої освіти 2019 (Кабінет міністрів України) Офріційний сайт Верховної Ради України. URL: https://zakon.rada.gov.ua/laws/show/635-2019-\%D0\%BF\#Text

Примірне положення про команду психолого-педагогічного супроводу дитини з особливими освітніми потребами в закладі загальної середньої та дошкільної освіти 2018 (Міністерство освіти та науки України). Офріційний сайт Верховної Ради України. URL: https://zakon.rada.gov.ua/rada/show/v060972918\#Text

Про встановлення тривалості здобуття повної загальної середньої освіти особами з особливими освітніми потребами у закладах загальної середньої освіти (Кабінет міністрів України). Офіційний сайт Верховної Ради України. URL: https://zakon.rada.gov.ua/laws/show/585-2003-\%D0\%BF/ed20190830\#Text

Про затвердження Програми професійної підготовки інвалідів по слуху і зору у вищих навчальних закладах I-IV рівнів акредитації. Наказ МОН та АПН від 17.11.2003 №764. Ооріційний сайт Верховної Ради України. URL: https://zakon.rada.gov.ua/rada/show/v0764290-03\#Text

Про затвердження Порядку організації інклюзивного навчання у загальноосвітніх навчальних закладах (Кабінет міністрів України). Офіційний сайт Верховної Ради України. URL: https://zakon.rada.gov.ua/laws/show/872-2011$\%$ D0\%BF\#Text

Про заходи щодо забезпечення пріоритетного розвитку освіти в Україні. Наказ Президента України від 30.09.2010 № 926 Офріційний сайт Верховної Ради України URL: https://zakon.rada.gov.ua/laws/show/926/2010\#Text

Саламанська декларація та рамки дій щодо освіти осіб з особливими освітніми потребами. Прийнята Всесвітньою конференцією щодо освіти осіб 3 особливими освітніми потребами від 10 червня 1994 р. URL: URL: https://zakon.rada.gov.ua/laws/show/995_001-94?lang=uk\#Text

Щербяк, Ю. А. (2018). Нормативно-правові аспекти інклюзивної освіти в Україні, Україна в умовах реформування правової системи: сучасні реалії та міжнародний досвід: Матеріали III Міжнародної науково-практичної конференції.

Children and Families Act 2014 URL: https://www.legislation.gov.uk/ukpga/2014/6/contents/enacted

The Flagship on Education for All and the Rights of Persons with Disabilities: Towards Inclusion - UNESCO, France, 2004. - 55 pg.

Special Educational Needs and Disabilities Act 2001 URL: legislation.gov.uk/ukpga/2001/10/2003-10-08

UNESCO International Bureau of Education: Inclusive education: the way of the future. In: International Conference on Education, 48th, pp. 1-37. Geneva (2008)

$\begin{array}{cccc} & \text { References } & \\ \text { UN Advisory } & \text { Committee (1982). Persons } & \text { World Programme of Action } \\ \text { concerning } & \text { Disabled } & \text { Persons. } & \text { URL: }\end{array}$
https://zakon.rada.gov.ua/laws/show/995_427?lang=uk\#Text

UN General Assembly (1959). Declaration of the Rights of the Child. URL: 
https://zakon.rada.gov.ua/laws/show/995_384?lang=uk\#Text

UN General Assembly (1971). Declaration of the Rights of Mentally Retarded

Persons. URL: https://zakon.rada.gov.ua/laws/show/995 119?lang=uk\#Text

Cabinet of Ministers of Ukraine (2013). Derzhavnyi standart pochatkovoi zahalnoi osvity dlia ditei z osoblyvymy osvitnimy potrebamy [State standard of primary general education for children with special educational needs]. URL: https://zakon.rada.gov.ua/laws/show/848-2004-\%D0\%BF\#Text)

UN General Assembly (1948). Universal Declaration of Human Rights. URL: https://zakon.rada.gov.ua/laws/show/995_015?lang=uk\#Text

Verkhovna Rada of Ukraine (2017). About the education. URL: https://zakon.rada.gov.ua/laws/show/2145-19\#Text

UN General Assembly (1960). Convention against Discrimination in Education. URL: https://zakon.rada.gov.ua/laws/show/995_174?lang=uk\#Text

UN General Assembly (2006). Convention on the Rights of Persons with Disabilities. URL: https://zakon.rada.gov.ua/laws/show/995 g71/ed20061213?lang=uk\#Text

Kryzhanivskyi V., Svarnyk N., Skrypka N. (2004). Kontseptsiia rannoi sotsialnoi reabilitatsii ditei-invalidiv: zbirnyk normatyvno-pravovykh aktiv Ukrainy shchodo diialnosti tsentriv reabilitatsii ditei iz funktsionalnymy obmezhenniamy [The concept of early social rehabilitation of children with disabilities], (pp 29-30). Kyiv: Sotsinform [In Ukrainian].

Cabinet of Ministers of Ukraine (2000). Kontseptsiia rannoi sotsialnoi reabilitatsii ditei-invalidiv [The concept of early social rehabilitation of children with disabilities].URL: https://zakon.rada.gov.ua/laws/show/1545-2000-\%D0\%BF\#Text

Ministry of Education and Science of Ukraine (2010). Kontseptsiia rozvytku inkliuzyvnoho navchannia [The concept of inclusive education development]. URL: https://mon.gov.ua/ua/npa/pro-zatverdzhennya-kontseptsii-rozvitku-inklyuzivnogonavchannya

Kryvoruchko, O. Yu., Shevchenko, M. S. (2021) Administratyvno-pravove rehuliuvannia inkliuzyvnoi osvity u zakladakh doshkilnoi ta povnoi zahalnoi serednoi osvity v Ukraini [Administrative and legal regulation of inclusive education in preschool and complete general secondary education institutions in Ukraine. Constitutional state]. Pravova derzhava, №. 41, 122-137. DOI: https://doi.org/10.18524/24112054.2021.41.225618

UN General Assembly (1966). International Covenant on Economic, Social and Cultural Rights. URL: https://zakon.rada.gov.ua/laws/show/995 042/ed19661216\#Text

Bronytskaia $Э$ (2011). Mizhnarodni standarty ta yevropeiska praktyka u sferi dostupnosti vyshchoi osvity [International standards and European practice in the field of accessibility of higher education]. https://www. disright.org/ru/info/mezhdunarodnye-standarty-i-evropeyskaya-praktika-vsfere-dostupnosti-vysshego-obrazovaniya

Cabinet of Ministers of Ukraine (2011). Poriadok orhanizatsii inkliuzyvnoho navchannia u zahalnoosvitnikh navchalnykh zakladakh [The procedure for organizing inclusive education in secondary schools]. URL: https://zakon.rada.gov.ua/laws/show/872-2011-\%D0\%BF/ed20110815\#Text

Cabinet of Ministers of Ukraine (2019). Poriadok orhanizatsii inkliuzyvnoho navchannia u zakladakh vyshchoi osvity [The procedure for organizing inclusive education in higher education institutions]. URL: https://zakon.rada.gov.ua/laws/show/635-2019-\%D0\%BF\#Text

Ministry of Education and Science of Ukraine (2018). Prymirne polozhennia pro komandu psykholoho-pedahohichnoho suprovodu dytyny z osoblyvymy osvitnimy potrebamy $v$ zakladi zahalnoi serednoi ta doshkilnoi osvity [The sample clause about 
the team of psychological and pedagogical support of a child with special educational needs in a general secondary and preschool institutions]. URL: https://zakon.rada.gov.ua/rada/show/v0609729-18\#Text

Cabinet of Ministers of Ukraine (2019). Pro vstanovlennia tryvalosti zdobuttia povnoi zahalnoi serednoi osvity osobamy z osoblyvymy osvitnimy potrebamy $u$ zakladakh zahalnoi serednoi osvity [About establishing a duration of full general secondary education for persons with special educational needs in general secondary education]. URL: https://zakon.rada.gov.ua/laws/show/585-2003\%D0\%BF/ed20190830\#Text

MESU and NAES (2003). Pro zatverdzhennia Prohramy profesiinoi pidhotovky invalidiv po slukhu i zoru u vyshchykh navchalnykh zakladakh I-IV rivniv akredytatsii [About the approval of the Program of professional training of visually and hearing impaired disabled persons in higher educational institutions of I-IV levels of accreditation]. URL: https://zakon.rada.gov.ua/rada/show/v0764290-03\#Text

Cabinet of Ministers of Ukraine (2011) Pro zatverdzhennia Poriadku orhanizatsii inkliuzyvnoho navchannia u zahalnoosvitnikh navchalnykh zakladakh [About approval of the Procedure for the organization of inclusive education in secondary schools]. URL: https://zakon.rada.gov.ua/laws/show/872-2011\%D0\%BF\#Text

President of Ukraine (2010). Pro zakhody shchodo zabezpechennia priorytetnoho rozvytku osvity $v$ Ukraini [About measures to ensure priority development of education in Ukraine]. https://zakon.rada.gov.ua/laws/show/926/2010\#Text

United nations of Educational, Scientific and Cultural Organization (1994). The Salamanca Statement and Framework for Action on Special Needs Education. URL: ttps://zakon.rada.gov.ua/laws/show/995_001-94?lang=uk\#Text

Shcherbiak Y. (2018). Normatyvno-pravovi aspekty inkliuzyvnoi osvity v Ukraini [Regulatory and legal issues of inclusive education in Ukraine]. Ukraine in the context of reforming the legal system: current realities and international experience, III International Scientific and Practical Conference.

UK HM Government (2014). Children and Families Act 2014. URL: https://www.legislation.gov.uk/ukpga/2014/6/contents/enacted

UNESCO (2004). The Flagship on Education for All and the Rights of Persons with Disabilities: Towards Inclusion. France, 55.

UK HM Government (2001) Special Educational Needs and Disabilities Act 2001. URL: https://www.legislation.gov.uk/ukpga/2001/10/2003-10-08

UNESCO (2008). International Bureau of Education: Inclusive education: the way of the future. International Conference on Education №48, Geneva, 1-37

\section{АНОТАЦІЯ}

Актуальність теми зумовлена необхідністю вдосконалення чинного законодавства та практики забезпечення права на рівний доступ до якісної освіти для дітей з особливими потребами. Нормативно-правові аспекти інклюзивної освіти вже були розглянуті в наукових виданнях України. Разом $з$ тим потребують додаткового аналізу нормативно-правові аспекти інклюзивної загальної середньої освіти.

Метою роботи є дослідження й аналіз нормативно-правових засад інклюзивної загальної середньої освіти та їх реалізація у світовому та вітчизняному досвіді.

Законодавчий процес забезпечення інклюзивної освіти в Украӥні багато в чому визначений міжнародними нормативно-правовими актами. Міжнародна стратеаія інклюзивної освіти спрямована на реалізацію прав людини на освіту, 
формування інклюзивного суспільства, трансформацію освітніх систем, підтримку державних стратегій інклюзивної освіти, модернізацію професійнопедагогічної підготовки вчителя, розроблення механізмів інвестування інклюзивної освіти.

У законодавстві України закладено основи для індивідуалізації освіти. Питання практичної реалізації Концепції розвитку інклюзивної освіти вимагають удосконалення. По-перше, це необхідність внесення змін до законів України "Про освіту", "Про дошкільну освіту" та "Про загальну середню освіту" щодо збільшення годин роботи асистента вихователя та асистента вчителя. По-друге, слід внести зміни щодо наповнюваності груп та класів таким чином, аби в межах одного класу могли знаходитися діти лише 3 однаковими видами порушень.

Ключові слова: інклюзивна освіта, особливі освітні потреби, інклюзія, загальна середня освіта, нормативно-правові аспекти освіти. 